\title{
To study the clinicobacteriological profile and antibiotic susceptibility pattern of community acquired pyodermas
}

\author{
Harshita ${ }^{1}$, Malhotra $S^{2}$, Malhotra S.K $\mathbf{K}^{3}$, Kaur $\mathbf{S}^{4}$ \\ ${ }^{1}$ Dr Harshita, JR, Department of Microbiology, ${ }^{2}$ Dr. Sita Malhotra, Associate Professor, Department of Microbiology, \\ ${ }^{3}$ Dr S.K. Malhotra, Professor and Head, Department of Skin and STD, ${ }^{4}$ Dr Shailpreet Kaur, Assitant Professor, \\ Department of Microbiology. All are affiliated with GMC, Amritsar, Punjab, India
}

Address for Correspondence: Dr Harshita, JR, Department of Microbiology, Email: harshitaguglani@yahoo.com

\begin{abstract}
Background: Pyodermas are the pyogenic skin infection encountered in dermatologic clinic and is mainly caused by Staphylococci and Streptococci. Aim: To find out causative organisms in community acquired pyodermas and their current antibiotic susceptibility patterns. Materials and Methods: All the patients attending the Dermatology OPD in Government Medical College, Amritsar were screened over 18 months and swabs were sent for culture and sensitivity. Results: The maximum incidence of pyodermas was observed in patients of 21-40 years i.e $82(51.24 \%)$. Most of the patients were males i.e 95(64\%) than females i.e 64(40\%). Out of 160 patients, maximum patients i.e. $109(68.13 \%)$ had secondary pyoderma and $51(31.87 \%)$ had primary pyodermas. Out of 160 samples, growth was obtained in $148(92.50 \%)$ samples while $12(07.50 \%)$ samples showed no growth. Most common organisms isolated was Staphylococcus aureus in 70 (43.75\%) cases followed by CONS in 20(12.50\%) cases. Among the Gram negative organisms E.coli was observed to be the common isolate in 16(10.00\%) cases followed by Pseudomonas aeruginosa in $12(07.50 \%)$ cases. On antibiotic susceptibility testing, Gram positive organisms, maximum sensitivity i.e $100 \%$ was seen to vancomycin, linezolid and maximum resistance i.e $84.29 \%$ was seen to ampicillin. Among the Gram negative isolates maximum sensitivity i.e $100 \%$ was seen to Imipenem, Piperacillin -Tazobactum and Sulbactam-Ceftazidime and maximum resistance i.e 100\% was seen to ceftazidime in case of Acinetobacter. Conclusion: This study gives an indication of the present pattern of bacteriological profile and antibiotic susceptibility pattern of pyodermas in a tertiary care hospital in north India.
\end{abstract}

Keywords: Pyodermas, Bacterial isolates, Antibiotic resistance.

\section{Introduction}

Pyodermas are one of the common skin problems in dermatology clinics in India [1]. Primary pyodermas are the infection of non diseased skin and its appendages. They tend to have a more characteristic course and morphology and includes impetigo, folliculitis, carbuncle, ecthyma and sycosis barbae [2]. Out of all the primary pyodermas, the incidence of Impetigo is reported to be the highest with involvement of the face because of its proximity to the common carrier site i.e nares, so that organisms can easily get disseminated via the fingers [2]. Whereas secondary pyodermas originate in the previously diseased skin as a superimposed condition and may not follow a characteristic course as

Manuscript received: $2^{\text {nd }}$ March 2016

Reviewed: $10^{\text {th }}$ March 2016

Author Corrected: $22^{\text {nd }}$ March 2016

Accepted for Publication: 01 ${ }^{\text {st }}$ April 2016 it leads to either acute or chronic intermingling state of underlying skin disease [3]. Secondary pyodermas include infected scabies, infected pemphigus, infected contact dermatitis, trophic ulcer and various other dermatosis infected with bacteria or other organisms [2]. These can be triggered by prior lesions, trauma, insect bite and secondary infections [3]. Most common organisms isolated in pyodermas are Staphylococcus aureus which may be (Methicillin sensitive or Methicillin resistant) followed by Streptococcus pyogenes. Other organisms which occasionally come across are Gram negative bacilli, [4,5,6], Corynebacterium species [7]. Many cases now a day do not respond to the selected antibiotic that was previously effective. Perhaps, indiscriminate use of antibiotics has contributed to this situation. The 
emergence of antibiotic resistance significantly poses a serious threat to public health. For the successful treatment of pyodermas, various causative organisms and their sensitivity patterns in local area is essential. The present study was an attempt to find out the causative organisms and their antibiotic susceptibility patterns in pyodermas in the Dermatology department in a tertiary care hospital.

\section{Material and Methods}

The present study was carried out on patients showing the clinical signs of pyoderma attending the out patient department of Dermatology at Government Medical College, Amritsar. This study was conducted over a period of one and half year from (Dec 2013-June 2015). Written informed consent was taken from every patient enrolled in the study. Due approval of the institutional ethical committee was taken before the commencement of the study. Detailed history and clinical examination of the patient were recorded in the proforma.

\section{Inclusion criteria:}

- Patients presenting to the Dermatology out patient department with purulent skin lesions for treatment for the first time.

- Patients of all ages and both the sexes were included.

Exclusion criteria

- H/o hospitalization in preceding one year.

- H/o antibiotic usage in last two weeks.

- H/o dialysis, surgery, indwelling catheter and medical devices which pass through skin to the body.

- Cases of resolving pyodermas.

Sample collection and transport: Before collecting samples from the lesion the surrounding area was

\section{Results}

Table 1: Age wise distribution of patients with community acquired pyodermas.

\begin{tabular}{|l|l|l|}
\hline Age & Number of cases & Percentage \% \\
\hline $1-10$ years & 16 & 10.00 \\
\hline $11-20$ years & 24 & 15.00 \\
\hline $21-30$ years & 47 & 29.38 \\
\hline $31-40$ years & 35 & 21.88 \\
\hline $41-50$ years & 17 & 10.62 \\
\hline $51-60$ years & 9 & 05.62 \\
\hline $61-70$ years & 7 & 04.38 \\
\hline $71-80$ years & 5 & 03.12 \\
\hline Total & 160 & 100 \\
\hline Mean age \pm SD & $\mathbf{3 1 . 0 7} \pm \mathbf{1 6 . 8 6}$ & \\
\hline
\end{tabular}

cleaned with $70 \%$ alcohol followed by $10 \%$ povidone iodine solution. Iodine was removed from the area with alcohol prior to the pus collection. The intact pustule was ruptured with sterile needle and the pus was taken with sterile cotton swab stick. In open wounds, the debris was removed as far as possible and the lesion rinsed thoroughly with sterile saline prior to material collection. All the samples were collected aseptically with two sterile cotton swabs for each sample from the lesion, which were processed for isolation and identification of bacterial pathogen, according to

Antibiotic susceptibility testing: All the organisms isolated were tested for antibiotic susceptibility pattern on Mueller Hinton agar using Kirby Bauer disc diffusion method as per CLSI guidelines [8].

The antimicrobial agents (Hi Media, Mumbai) which were tested: Ampicillin $(10 \mu \mathrm{g})$, amoxicillin / clavulinic acid $(20 / 10 \mu \mathrm{g})$, gentamycin $(10 \mu \mathrm{g})$, cotrimoxazole $(25 \mu \mathrm{g})$ Ciprofloxacin $(5 \mu \mathrm{g})$, erythromycin $(15 \mu \mathrm{g})$, cefadroxil $(30 \mu \mathrm{g})$, cefalexin $(30 \mu \mathrm{g})$, linezolid $(30 \mu \mathrm{g})$, vancomycin $(30 \mu \mathrm{g})$ for Gram positive organisms. For Gram negative organisms, amikacin $(30 \mu \mathrm{g})$, gentamycin $(10 \mu \mathrm{g})$, ciprofloxacin $(5 \mu \mathrm{g})$, piperacillin $(100 \mu \mathrm{g})$, piperacillin + tazobactum $(100 / 10 \mu \mathrm{g})$, Cefotaxime $(30 \mu \mathrm{g})$, sulbactum + cefotaxime $(10 / 30 \mu \mathrm{g})$. The diameter of zone of inhibition will be measured and interpreted as susceptible, intermediate or resistant. For detection of MRSA cefoxitin disc diffusion technique was used as per CLSI guidelines[9].

Statistical Analysis: Results obtained from the study were compiled and statistically analysed. standard microbiological techniques. 
Table 2: Clinical diagnosis of pyodermas

\begin{tabular}{|l|l|l|l|l|l|}
\hline $\begin{array}{l}\text { Clinical Types of } \\
\text { primary } \\
\text { pyodermas }\end{array}$ & $\begin{array}{l}\text { No. of } \\
\text { patients }\end{array}$ & $\begin{array}{l}\text { Percentage } \\
(\%)\end{array}$ & $\begin{array}{l}\text { Clinical types of } \\
\text { secondary pyodermas }\end{array}$ & No. of patients & Percentage \\
\hline $\begin{array}{l}\text { Impetigo } \\
\text { contagiosa }\end{array}$ & 16 & 31.40 & Infected eczema & 55 & 50.46 \\
\hline Furuncle & 11 & 21.56 & Infected ulcer & 40 & 36.70 \\
\hline Folliculitis & 10 & 19.60 & Pustular lesions & 08 & 07.34 \\
\hline Cellulitis & 4 & 07.84 & Infected scabies & 02 & 01.83 \\
\hline Paronychia & 4 & 07.84 & Infected psoriasis & 01 & 00.92 \\
\hline Carbuncle & 3 & 05.88 & $\begin{array}{l}\text { Irritant contact dermatitis } \\
\text { with secondary infection }\end{array}$ & 02 & 01.83 \\
\hline Bullous impetigo & 3 & $\begin{array}{l}\text { Herpes zoster with } \\
\text { secondary infection }\end{array}$ & 01 & 00.92 \\
\hline Total & $\mathbf{5 1}$ & $\mathbf{1 0 0 . 0 0}$ & Total & $\mathbf{1 0 9}$ & $\mathbf{1 0 0 . 0 0}$ \\
\hline
\end{tabular}

Table 3: Showing number and type of microorganisms isolated from all the cases of community acquired primary Pyodermas

\begin{tabular}{|c|c|c|c|c|c|c|c|}
\hline \multicolumn{2}{|c|}{$\begin{array}{l}\text { Organisms isolated in } \\
\text { primary pyodermas }\end{array}$} & \multirow{2}{*}{$\begin{array}{l}\text { No. Of } \\
\text { patients } \\
(\mathbf{n}=\mathbf{5 1})\end{array}$} & \multirow{2}{*}{$\begin{array}{l}\text { Percentage } \\
\%\end{array}$} & \multicolumn{2}{|c|}{$\begin{array}{l}\text { Organisms isolated in } \\
\text { secondary pyodermas }\end{array}$} & \multirow{2}{*}{$\begin{array}{l}\text { No of } \\
\text { patients } \\
46\end{array}$} & \multirow{2}{*}{$\begin{array}{l}\text { Percentage } \\
\% \\
42.20\end{array}$} \\
\hline Staphylococcus & MSSA & & & Staphylococcus & MSSA & & \\
\hline Aureus & MRSA & 0 & 00.00 & Aureus & MRSA & 4 & 03.67 \\
\hline \multicolumn{2}{|c|}{$\begin{array}{l}\text { Coagulase negative } \\
\text { Staphylococcus }\end{array}$} & 8 & 15.69 & Escherichia coli & & 16 & 14.68 \\
\hline \multicolumn{2}{|l|}{ Klebsiellaspp } & 4 & 07.84 & $\begin{array}{l}\text { Coagulase } \\
\text { negative } \\
\text { Staphylococcus }\end{array}$ & & 12 & 11.00 \\
\hline \multirow[t]{2}{*}{$\begin{array}{l}\text { Enterococcus } \\
\text { spp }\end{array}$} & VSE & 4 & 07.84 & $\begin{array}{l}\text { Pseudomonas } \\
\text { aeruginosa }\end{array}$ & & 8 & 07.34 \\
\hline & VRE & 0 & 00.00 & Proteus spp & & 7 & 06.42 \\
\hline \multicolumn{2}{|c|}{ Pseudomonas aeruginosa } & 4 & 07.84 & Klebsiellaspp & 4 & & 03.67 \\
\hline \multicolumn{2}{|l|}{ Citrobacterspp } & 2 & 03.92 & Enterococcus & VSE & 5 & 04.60 \\
\hline \multirow{4}{*}{\multicolumn{2}{|c|}{ No growth }} & 9 & 17.65 & & VRE & 1 & 00.92 \\
\hline & & & & Acinetobacterspp & 2 & & 01.83 \\
\hline & & & & Citrobacterspp & 1 & & 00.92 \\
\hline & & & & No growth & 3 & & 02.75 \\
\hline
\end{tabular}

The present study comprised of 160 patients with pyoderma skin lesions, maximum incidence i.e 47(29.38\%) cases of pyodermas were observed in patients of 21-30years of age group followed by 35 (21.88\%) in 31-40 years.(table 1). Out of 160 patients, $96(60 \%)$ were males and $64(40 \%)$ were females with an overall male to female ratio of $3: 2$. Out of 160 patients, 66 cases were of primary Pyoderma and 34 were of secondary pyoderma. Among the primary pyoderma, Impetigo contagiosa in $16(31.40 \%)$ cases was the most common clinical type followed by Folliculitis in $10(19.60 \%)$ cases. Among the secondary Pyoderma, Eczema with secondary infection in 55(50.46\%) cases was most common followed by infected ulcer in $40(36.70 \%$ ) cases.(Table 2). On bacteriological examination of 160 samples obtained from pyogenic lesions, growth was obtained in $148(92.50 \%)$ samples, among them single organism was isolated in 144 (97.29\%) and mixed growth was obtained in 4(02.70\%) samples 
Table 4: showing sensitivity profile of various bacterial isolates, isolated from the cases of prodermas

\begin{tabular}{|c|c|c|c|c|c|c|c|c|c|}
\hline $\begin{array}{l}\text { Antibiotic } \\
\text { tested }\end{array}$ & $\begin{array}{l}\text { Staphylo } \\
\text { coccus } \\
\text { aureus(n } \\
=70)\end{array}$ & $\begin{array}{l}\text { CON } \\
S \\
(n=2 \\
0)\end{array}$ & $\begin{array}{l}\text { Enteroc } \\
\text { occus } \\
(n=10)\end{array}$ & $\begin{array}{l}\text { E.coli } \\
(n=16)\end{array}$ & $\begin{array}{l}\text { Pseudo } \\
(n=12)\end{array}$ & $\begin{array}{l}\text { Klebsiel } \\
\text { la } \\
(n=8)\end{array}$ & $\begin{array}{l}\text { Proteus } \\
(n=7)\end{array}$ & $\begin{array}{l}\text { Citrob } \\
\text { acter } \\
(n=3)\end{array}$ & $\begin{array}{l}\text { Acineto } \\
\text { bacter } \\
(n=2)\end{array}$ \\
\hline Ampicillin & S11(15.71) & $\begin{array}{l}\mathrm{S} 5(25 \\
)\end{array}$ & S2(20) & NT & NT & NT & NT & NT & NT \\
\hline Amikacin & S67(95.71) & $\begin{array}{l}\text { S17(8 } \\
5)\end{array}$ & S8(80) & $\begin{array}{l}\text { S15(93.7 } \\
5)\end{array}$ & $\begin{array}{l}\text { S11(91.6 } \\
6)\end{array}$ & $\mathrm{S} 8(100)$ & S6(85.71) & S3(100) & NT \\
\hline Gentamycin & S51(72.85) & $\begin{array}{l}\text { S14(7 } \\
0)\end{array}$ & S7(70) & S12(75) & $\begin{array}{l}\mathrm{S} 10(83.3 \\
3)\end{array}$ & $\begin{array}{l}S 7(87.50 \\
)\end{array}$ & S5(71.43) & $\begin{array}{l}S 2(66.6 \\
6)\end{array}$ & S1(50) \\
\hline Ciprofloxacin & S35(50.00) & $\begin{array}{l}\text { S14(7 } \\
0)\end{array}$ & S6(60) & $\begin{array}{l}\text { S10(62.5 } \\
0)\end{array}$ & $\begin{array}{l}\mathrm{S} 10(83.3 \\
3)\end{array}$ & $\mathrm{S} 5(41.60$ & S4(57.14) & S3(100) & S1(50) \\
\hline Erythromycin & S53(75.71) & $\begin{array}{l}\text { S15(7 } \\
5)\end{array}$ & S8(80) & NT & NT & NT & NT & NT & NT \\
\hline Cephalexin & S27(38.57) & $\begin{array}{l}\mathrm{S} 8(40 \\
)\end{array}$ & S5(50) & NT & NT & NT & NT & NT & NT \\
\hline Cefoxitin & $\begin{array}{l}\text { S66(94.28) } \\
\text { R4(5.71) }\end{array}$ & $\begin{array}{l}\text { S20(1 } \\
00)\end{array}$ & NT & NT & NT & NT & NT & NT & NT \\
\hline $\begin{array}{l}\text { Cotrimoxazol } \\
\text { e }\end{array}$ & S39(55.71) & $\begin{array}{l}\text { S12(6 } \\
0)\end{array}$ & S6(60) & NT & NT & NT & NT & NT & NT \\
\hline Linezolid & S70(100) & $\begin{array}{l}\text { S20(1 } \\
00)\end{array}$ & S10(100) & NT & NT & NT & NT & NT & NT \\
\hline Vancomycin & S70(100) & $\begin{array}{l}\text { S20(1 } \\
00)\end{array}$ & S9(90) & NT & NT & NT & NT & NT & NT \\
\hline A-clav & S66(94.28) & $\begin{array}{l}\text { S20(1 } \\
00)\end{array}$ & NT & NT & NT & NT & NT & NT & NT \\
\hline Ceftazidime & NT & NT & NT & $\begin{array}{l}\text { S10(62.5 } \\
0)\end{array}$ & $\begin{array}{l}\mathrm{S} 5(41.66 \\
)\end{array}$ & $\begin{array}{l}\mathrm{S} 3(37.50 \\
)\end{array}$ & S2(28.57) & $\begin{array}{l}\text { S1(33.3 } \\
3)\end{array}$ & S0(0) \\
\hline $\begin{array}{l}\text { Pipercillin- } \\
\text { tazobactam }\end{array}$ & NT & NT & NT & $\begin{array}{l}\text { S15(93.7 } \\
5)\end{array}$ & $\begin{array}{l}\text { S11(91.6 } \\
6)\end{array}$ & S8(100) & S7(100) & S3(100) & S2(100) \\
\hline $\begin{array}{l}\text { Salbactam- } \\
\text { ceftazidime }\end{array}$ & NT & NT & NT & $\begin{array}{l}\mathrm{S} 13(81.2 \\
5)\end{array}$ & $\begin{array}{l}\mathrm{S} 10(83.3 \\
3)\end{array}$ & $\begin{array}{l}\mathrm{S} 7(87.50 \\
)\end{array}$ & S5(71.43) & S3(100) & S2(100) \\
\hline Imipenem & NT & NT & NT & S16(100) & S12(100) & S8(100) & S7(100) & S3(100) & S2(100) \\
\hline
\end{tabular}

NT-not tested, S-sensitive, R-resistant.

Among the 51 patients of primary pyoderma, bacterial growth was obtained on culture in 42(82.33\%) samples. Staphylococcus aureus was the commonest isolate in 20(39.22\%) samples followed by Coagulase negative Staphylococci in $8(15.69 \%)$ samples. On bacteriological examination of 109 samples of secondary pyodermas, the culture growth showed that Staphylococcus aureus was the commonest isolates in 46(42.20\%) samples followed by Escherichia coli in $16(14.68 \%)$ samples.(Table 3) Out of 50 isolates of Staphylococcus aureus, Methicillin resistance was seen in 4(03.67\%) samples and rest of the 46(42.20\%) samples were observed to be Methicillin sensitive. Among the 6 samples of Enterococcus spp, Vancomycin resistance was seen in $1(00.92 \%)$ sample and it was sensitive in 5(04.60\%) samples.(Table 3).

Among all the isolates of Staphylococcus, maximum sensitivity i.e 100\% was seen to Vancomycin and Linezolid followed by Amikacin (95\%) and Amoxicillin clavulanic acid (94.28\%) and maximum resistance (84.29\%) was seen to Ampicillin followed by Cephalexin $(61.43 \%)$ and ciprofloxacin $(50 \%)$. Erythromycin which is an alternative drug to Ampicillin showed resistance in $24.29 \%$ of isolates.

Methicillin resistance in Staphylococcus aureus was detected by cefoxitin disc diffusion method. Methicillin resistance was observed in $4(05.71 \%)$ cases of community acquired pyodermas. Among the Coagulase Negative Staphylococci 
isolates, maximum sensitivity was observed to linezolid, vanmcomycin and Amoxicillin-clavulanic acid, 100\% each, followed by amikacin (85\%) and maximum resistance i.e $75 \%$ was seen to ampicillin followed by cephalexin $(60 \%)$. Among Enterococcus spp, maximum sensitivity i.e 100\% was seen to Linezolid and maximum resistance i.e $80 \%$ was seen to Ampicillin. Only one isolate (10\%) was observed to be resistant to vancomycin in community acquired pyodermas. All the Gram negative isolates showed maximum sensitivity (100\%) to Imipenem. 100\% sensititvity to piperacillin-tazobactam was observed in case of Acinetobacter, Citrobacter, Klebsiella and Proteus except E.coli and Pseudomonas aeruginosa which showed $93.75 \%$ and $91.66 \%$ respectivelyAcinetobacter spp and Citrobacter spp also showed $100 \%$ sensitivity to salbactam-ceftazidime except Klebsiella spp which showed in $87.50 \%$ sensitivity to sulbactam-ceftazidime followed by Pseudomonas aeruginosa (83.33\%), Escherichia coli (81.25\%) and Proteus (71.43\%).(Table 4).

\section{Discussion}

This study showed that most of the cases of pyodermas i.e $82(51.24 \%)$ were observed in $21-40$ years of age group (Table 1). Mean age was found to be $31.07 \pm 16.86$. Similar results were reported by Paudel $U$ et al, who observed $42(56.00 \%)$ cases in the age group of 21-40 years [4]. Reason could be due to the early reporting to paediatric or surgical clinics while suffering from their primary infections [10]. In this study out of 160 patients, $96(60 \%)$ were males and 64(40\%) were females and male to female ratio was 3:2. Similar findings of male preponderance in their studies were observed by Chaudhary et al, in 95(63.33\%), Gandhi et al,in 124(61.2\%)[11], whereas female preponderance was observed by Neirita $H$, in $83(53 \%)$ and Mathew et al, in $72(60 \%)$ of their cases[12,13]. The reason for the male predominance in this study could be due to more outdoor activities of the males than the females which lead to increased incidence of microtrauma [4].

In this study primary pyodermas were seen in $51(31.87 \%)$ cases while the secondary pyodermas were recorded in $109(68.13 \%)$ cases. Similar study was done by Malhotra SK et al which showed $49(80.33 \%)$ cases of secondary pyodermas and $12(19.67 \%)$ cases of primary pyodermas [14]. In our study various risk factors like poverty, malnutrition, overcrowding and poor hygiene have been observed to be responsible for the higher incidence of pyodermas in the lower socioeconomic strata [8]. In this study, majority of the cases i.e $101(63.13 \%)$ belonged to the lower socio-economic groups which were associated with poor housing standards, poor personal hygiene in $86(54 \%)$ cases and overcrowding in $85(53 \%)$ cases. $48 \%$ of our cases were malnourished which contributes to the lower immunity levels and thereby precipitates skin infections. This was in accordance with the study done by Nierita $\mathrm{H}$ in which they showed poor personal hygiene in $52 \%$, overcrowding in 53\% and malnourished in $46 \%$ cases [13]. There was no correlation of family history seen in our study. In the present study maximum numbers of cases were reported in summers i.e $82(51.25 \%)$. Other similar studies which observed maximum cases during summer season were done by Neirita $\mathrm{H}$ which showed $61(38.12 \%)$ cases and $U$ Paudel et al reported in $41(54.7 \%)$ cases[12,13].

In the present study out of 51 cases of primary pyodermas, impetigo was observed in16 (31.37\%) followed by furuncle in $11(21.56 \%)$ and folliculitis in $10(19.60 \%)$ cases respectively. Malhotra SK et al, in their study also reported impetigo to be the commonest entity in $9(14.75 \%)$ out of 61 cases [13]. Similar results were obtained by Tushar.S et al who also reported $17(26 \%)$ out of 64 cases of impetigo in their study [15].

Among 109 cases of secondary pyodermas infected eczema was found to be the most common clinical diagnosis in $55(50.45 \%)$ cases followed by infected ulcer in $40(36.69 \%)$ cases). Similar results were reported by Chaudhary et al who showed infected eczema to be the commonest clinical types in secondary pyoderma in 24(48.98\%) out of 34 cases [16].

In our study, lower limbs were found to be the commonest site to be affected, accounting for $66(41.25 \%)$ cases followed by upper limbs in $38(23.75 \%)$ cases. Ojha et al, also reported lower limb to be the most common site involved in $120(60 \%)$ cases [3]. Out of 160 samples, $148(92.50 \%)$ were found to be culture positive while $12(07.50 \%)$ were culture negative. Out of the culture positive (148) cases, pure single growth was obtained in $144(97.29 \%)$ while $4(02.70 \%)$ samples showed mixed growth of organisms.

In our study the most common organism isolated was Staphylococcus aureus which accounted for $70(43.75 \%)$ cases followed by CONS in $20(12.50 \%)$ cases. Mixture of both the organisms was isolated in $2(01.35 \%)$ cases. Out of 51 cases of primary pyodermas, Staphylococcus was isolated in $28(54.98 \%)$ samples, among them 20(39.21\%) were coagulase positive and $8(15.68 \%)$ were coagulase negative. While in secondary 
pyodermas out of $62(56.85 \%)$ isolates of Staphylococcus, coagulase positive isolates were $46(42.19 \%)$ and coagulase negative in $12(11.00 \%)$ samples.The findings of the present study regarding organisms isolated in pyoderma are in concordance with studies done by Malhotra SK et al. who reported $36(49.15 \%)$ cases of Staphylococcus out of which $21(34.41 \%)$ were coagulase positive and 9(14.755) were coagulase negative [14]. Other organisms isolated in our study were Escherichia coli 16(10.00\%), Pseudomonas aeruginosa 12(07.50\%), Enterococcus spp 10(06.25\%) Klebsiella spp 8(05.00\%), Proteus spp 7(04.37\%), Citrobacter spp 3(01.87\%) and Acinetobacter spp2(01.25\%). Mixed growth was seen in $4(02.70 \%)$ cases and no growth was obtained in 12 $(07.50 \%)$ cases. Similar results were obtained by Janardhan et al. who observed Escherichia coli in 6\% and Pseudomonas spp in $7 \%$ as the most common isolate among the Gram negative organisms [17].

There was no case of isolation of Streptococcus pyogenes in our study while most studies have shown significant isolation rate of Streptococcus pyogenes, either alone or mixed with Staphylococcus aureus. Due to the changing trend in the etiological agent there was high isolation rate of Staphylococcus aureus in our study. The reason behind this could be due to the inhibition of Streptococcus pyogenes by the secondary invasion by the Staphylococcus aureus which is supposed to produce bacteriocin, toxic to Streptococci or due to bacterial interference[4]. Among all the isolates of Staphylococcus, maximum sensitivity $(100 \%)$ was seen to Vancomycin and Linezolid followed by Amikacin (95.71\%) and Amoxicillin clavulanic acid (94.28\%) and maximum resistance (84.29\%) was seen to Ampicillin followed by Cephalexin (61.43\%) and ciprofloxacin (50\%). Erythromycin which is an alternative drug to Ampicillin showed resistance in $24.29 \%$ of isolates. Similar results were reported by Ojha et al, who observed Staphylococcus aureus isolates to be $99.35 \%$ sensitive to vancomycin and $94.35 \%$ sensitive to amoxyclav [3]. Patil et al in their study also reported $100 \%$ sensitivity of Staphylococcal isolates to vancomycin [18] Methicillin resistance in Staphylococcus aureus was detected by cefoxitin disc diffusion method. Among the 70 isolates of Staphylococcal aureus isolated from cases of secondary pyodermas, Methicillin resistance was observed in $4(05.71 \%)$ cases (Table 16 , Fig 16) This is in accordance with the study done by Tan et al, who reported $7 \%$ isolation rate of MRSA [15].
Among the Coagulase Negative staphylococci isolates maximum sensitivity was observed to linezolid, vancomycin and Amoxicillin-clavulanic acid, 100\% each, followed by amikacin (85\%) and maximum resistance was seen to ampicillin (75\%) followed by cephalexin $(60 \%)$. Similar results were obtained by study conducted by Janardhan et al reported $100 \%$ resistance to ampicillin [17]. This high resistance of ampicillin is probably due to the production of the $\beta$ lactamase enzymes. Among Enterococcus spp, maximum sensitivity (100\%) was seen to Linezolid. Maximum resistance $(80 \%)$ was seen to Ampicillin. Only one isolate $(10 \%)$ was observed to be resistant to vancimycin in secondary pyodermas whereas no case of vancomycin resistance was observed in primary pyodermas.

All the Gram negative isolates showed maximum sensitivity $(100 \%)$ to Imipenem. $100 \%$ sensititvity to piperacillin-tazobactam was observed in case of Acinetobacter, Citrobacter, Klebsiella and Proteus except E.coli and Pseudomonas aeruginosa which showed $93.75 \%$ and $91.66 \%$ sensititvity to piperacillin and tazobactam respectively. Acinetobacter spp and Citrobacter spp also showed $100 \%$ sensitivity to salbactam-ceftazidime except Klebsiella spp (87.50\%), Pseudomonas aeruginosa (83.33\%), Escherichia coli $(81.25 \%)$ and Proteus (71.43\%). This high level of resistance to third generation cephalosporins could be due to the widespread use of antibiotics leading to selective survival advantage of pathogen [19].

\section{Conclusion}

This study gives an indication of present pattern of bacterial infections in pyodermas and it also draws attention to the fact that multi drug resistance pattern was observed in cases of community acquired pyoderma to commonly used drugs. With the available evidence from current literature the antibiotic resistance has been on the increase in developing countries. Infection with resistant organisms has been associated with treatment failure, higher morbidity and mortality and increased costs. Therefore proper knowledge of antimicrobial susceptibility pattern of common pathogens of pyodermas helps to form the choice of antibiotics.

\section{Funding: Nil}

Conflict of interest: None. Permission of IRB: Yes 


\section{References}

1. Mehta TK. Pattern of skin diseases in India. Ind J Dermatol Venerol, 1962;28(3):134-9.

2. Gandhi S, Ojha AK, Ranjan KP, Neelima. Clinical and bacteriological aspects of pyoderma. N Am J Med Sci. 2012 Oct;4(10):492-5. doi: 10.4103/19472714.101997.

3. Paudel U, Parajuli S, Pokhrel DB. Clinicobacteriological profile and antibiotic susceptibility pattern in pyodermas: A hospital based study.Nep J Dermatol Venereol Leprol. 2013;11(1):49-57.

4.Nagmoti JM, Patil CS, Metgud SC. A bacterial study of pyoderma in Belgaum. Indian J Dermatol Venereol Leprol. 1999 Mar-Apr;65(2):69-71.

5. Ramani TV and Jayakar PA: Bacteriological study of 100 cases of Pyodermas with special reference to Staphylococci, antibiotic sensitivity and phage pattern. Ind J Dermatol Venereol Leprol. 1980;46(5):282-286.

6. Tan Hiok Hee. A study of bacterial skin infection in NSC. NSC Bulletin for Medical Practitioners. 1996;7(2).

7. Ayyagari A, Agarwal KC, Kaur S, Iyer RV, Kumar B. Prevalence of Corynebacterium diphtheriae in pyoderma and other skin lesions. ndian J Pathol Microbiol. 1979 Jan;22(1):37-45.

8. Clinical Laboratories Standard Institute. Performance standards for antimicrobial disks susceptibility tests. Approved standards, $11^{\text {th }}$ ed. CLSI document M2-A12. CLSI, Wayne, PA: CLSI 2012.

9. Park K. Health information and basic medical statistics. In: Park K, Park's textbook of preventive and social medicine. $21^{\text {st }}$ ed. Bansari das Bhanot, India; 2011.p.779-92.

10. Kharel C, Pandey SS, Agrawal S, Khanal B. Clinico-bacteriological study of pyoderma in children. Nep J Dermatol Venereol Leprol. 2012;10(1):11-5.

11. Janardhan. B, Prasad.G K, Nandeshwar AJ and Vidyavathi N. Clinico-microbiological study of pyodermas. International Journal of Recent Scientific Research. 2015;6(5):3820-3824.

12. Mathews MS, Garg BR, Kanungo R. A clinicobacteriological study of primary pyodermas in children in Pondicherry. Ind $\mathrm{J}$ Dermatol Venereol Leprol. 1992;58(3):183-7.

13. .Neirita Hazarika A Clinico-Epidemiological Study of Pyoderma in Children. Nat.J.Res.Com.Med. 2012;1(4):178 -241.

14. Malhotra SK, Malhotra S, Dhaliwal GS, Thakur A. Bacteriological study of pyodermas in a tertiary care dermatological center. Indian J Dermatol. 2012 Sep;57(5):358-61. doi: 10.4103/0019-5154.100475.

15. Sonaiya $\mathrm{T}$, Javedkar $\mathrm{T}$, Patel $\mathrm{S}$, Kinariwala $\mathrm{D}$, Govind N. Clinico-bacteriological study of pyoderma with special reference to community acquired methicillin resistant Staphylococcus aureus. Nat J Int Res Med. 2012;3(1):21-5.

16. Sanjiv Choudhary, Taru Aghi, Shilpi Basak, and Adarshlata Singh Clinico-Bacteriological Study of Pyoderma with Special Reference to Antibiotic Sensitivity in a Tertiary Care Rural Hospital. RJPBCS. 2015;6(2):1701.

17. Janardhan. B, Prasad.G K, Nandeshwar AJ and Vidyavathi N. Clinico-microbiological study of pyodermas. International Journal of Recent Scientific Research Research. 2015;6(5):3820-3824.

18. Patil R, Baveja S, Nataraj G, Khopkar U. Prevalence of methicillin-resistant Staphylococcus aureus (MRSA) in community-acquired primary pyoderma. Indian J Dermatol Venereol Leprol. 2006 Mar-Apr;72(2):126-8.

19. Mohanty S, Kapil A, Dhawan B, Das BK. Bacteriological and antimicrobial susceptibility profile of soft tissue infections from Northern India. Indian $\mathbf{J}$ Med Sci. 2004 Jan;58(1):10-5.

\section{How to cite this article?}

Harshita, Malhotra S, Malhotra S.K, Kaur S. To study the clinicobacteriological profile and antibiotic susceptibility pattern of community acquired pyodermas: Int J Med Res Rev 2016;4(3):437-443. doi: 10.17511/ijmrr.2016.i03.27. 